\title{
Predation by a Black-headed Ibis, Threskiornis melanocephalus (Latham 1790), on a Common Smooth-scaled Watersnake, Enhydris enhydris (Schneider 1799)
}

Khan Ashaharraza ${ }^{1}$ and Aloke Patnaik ${ }^{2}$

${ }^{1}$ Department of Wildlife and Biodiversity Conservation, North Orissa University, Baripada-757003, Odisha, India (ashaharrazakhan@gmail.com) 22197, Bakshi Jagbandhu Nagar, Canal Road, Bhubaneshwar-751014, Odisha, India (draloke@gmail.com)

$\mathrm{T}$ he Black-headed Ibis (Threskiornis melanocephalus) is a resident breeder but also a local migrant in India (Ali 1941). This large wading communal species forages on shallow mudflats along a variety of wetlands. Although widely distributed in southern and southeastern Asia (eBird 2018), the population, which is estimated at 10,000 individuals, is declining, and the species is listed as Near Threatened on the IUCN Red List of Threatened Species (Birdlife International 2016). Despite the species' extensive range, relatively little information about its natural history is available.

On 30 December 2017, we visited Manglajodi on the northern edge of Chilika Lake in Khurda District, Odisha, India (19 $\left.53^{\prime} 44.94^{\prime \prime} \mathrm{N}, 85^{\circ} 26^{\prime} 13.44^{\prime \prime} \mathrm{E}\right)$ to evaluate the status of winter migratory waterfowl (Changder et al. 2015). Chilika Lagoon is situated on India's eastern coast and connects to the Bay of Bengal. It is the largest brackish water wetland in India and was designated a Ramsar Site in 1981 (Tripathy 2012). At 0925 h, we observed a pair of Black-headed Ibis (Threskiornis melanocephalus) foraging in a shallow wetland with emergent vegetation and reed beds consisting mostly of cattails (Typha angustata) and grasses (Phragmites karka; Pattanaik et al. 2008). While we were watching, one of birds caught a snake (Fig. 1) and swallowed it headfirst. Unlike most wading birds, T. melanocephalus does not probe with its bill while searching for food items but instead targets its prey directly.

The snake was olive-brown above and ventrals were yellow with brown outer edges and a central row of brown spots, matching the description of the Common Smooth-scaled Watersnake, Enhydris enhydris (Schneider 1799) in Whitaker and Captain (2004). This first record of a Black-headed Ibis, previously known to feed on mollusks, crustaceans, insects, and worms (e.g., Jerdon 1864; Mason 1911), eating a snake adds $T$. melanocephalus to the list of natural predators of E. enhydris.

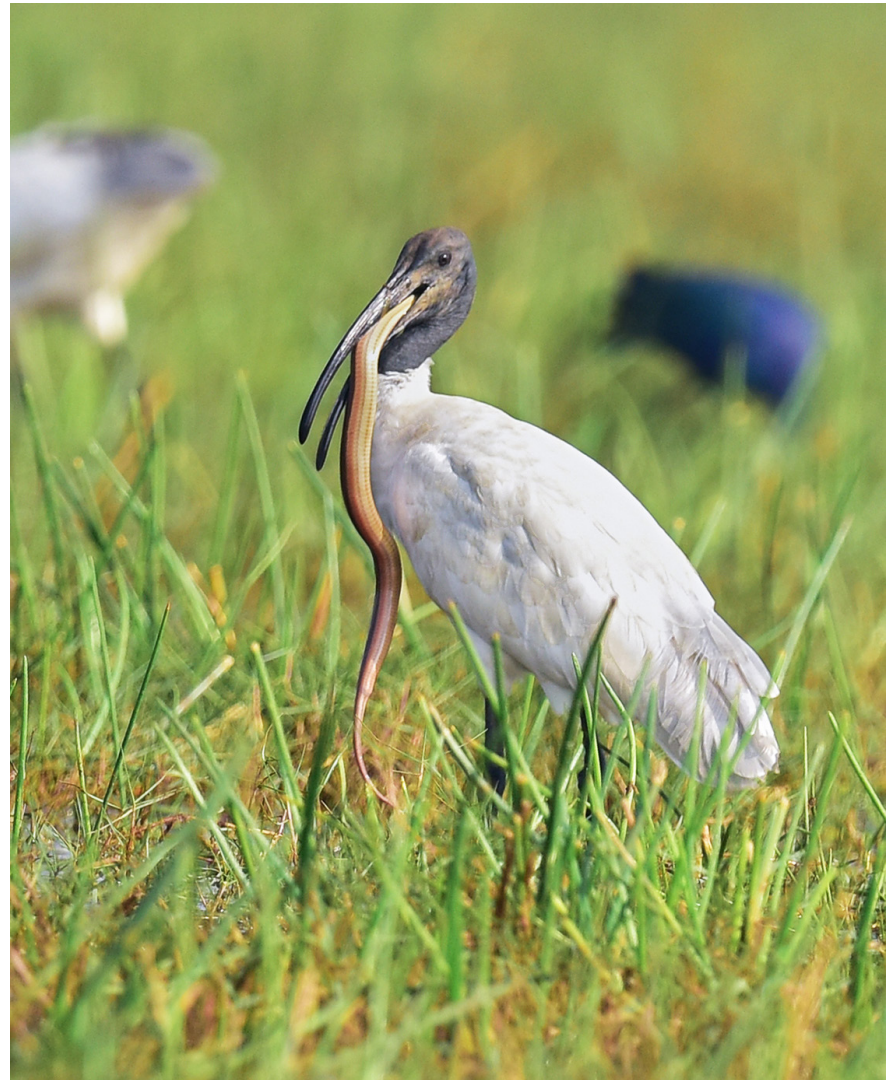

Fig. 1. A Black-headed Ibis (Threskiornis melanocephalus) preying on a Common Smooth-scaled Watersnake (Enhydris enhydris) in the Manglajodi Wetland, Odisha, India. Photograph by Aloke Patnaik.

\section{Acknowledgements}

We thank Asad Rahmani, former Director, Bombay Natural History Society, for encouraging publication and Pratyush Mohapatra, Central Zone Regional Centre, Zoological Survey of India, Jabalpur, for help with the literature. 


\section{Literature Cited}

Ali, S. 1941. The Book of Indian Birds. Bombay Natural History Society, Mumbai, India.

Changder, S., S. Adhurya, U. Roy, and M. Banerjee. 2015. A report on midwinter bird diversity from Mangalajodi Wetland, Odisha. ZOO's Print Journal 30(12): $1-5$.

eBird. 2018. Black-headed Ibis. Cornell Lab of Ornithology, College of Agriculture and Life Sciences, Cornell University, Ithaca, New York (https://ebird.org/map/blhibil?neg=true\&env. $\operatorname{minX}=\&$ env. $\min Y=\& e n v \cdot \max X=\&$ env $\cdot \max Y=\& z h=$ false $\& \mathrm{gp}=$ false\&ev $=Z \& m r=1-$ $12 \& \mathrm{bmo}=1 \&$ emo $=12 \& \mathrm{yr}=\mathrm{all} \& \mathrm{byr}=1900 \&$ eyr $=2018$ ).

Grimmette, K., C. Inskipp, and T. Inskipp. 2008. Birds of Indian Subcontinent. Oxford University Press, New Delhi, India.

Birdlife International. 2016. Threskiornis melanocephalus The IUCN Red List of Threatened Species 2016: e.T22697516A93618317 (http://dx.doi. org/10.2305/IUCN.UK.2016-3.RLTS.T22697516A93618317.en).

Jerdon, T.C. 1864. The Birds of India: Being a Natural History of All the Birds Known to Inhabit Continental India; with Descriptions of the Species, Genera, Families, Tribes, and Orders, and a Brief Notice of Such Families as are not Found in India, Making it a Manual of Ornithology Specially Adapted for India. Vol. III. George Wyman and Co. Publishers, Calcutta, India.

Mason, C.W. 1911. The food of birds in India. Memoirs of the Department of Agriculture in India. Entomological Series 3: iv $+371 \mathrm{pp}$.

Pattanaik, C., S.N. Prasad, and C.S. Reddy. 2008. Mangalajodi Wetland: Priority site for conservation. Current Science 95: 816-817.

Tripathy, M. 2012. Biodiversity of Chilika and its conservation, Odisha, India. International Research Journal of Environment Sciences 1(5): 54-57.

Whitaker, R. and A. Captain. 2008. Snakes of India: The Field Guide. Draco Books, Chennai, India. 